\title{
PTPN22 polymorphisms may indicate a role for this gene in atopic dermatitis in West Highland white terriers
}

\author{
Joana Barros Roque ${ }^{1}$, Caroline A O'Leary ${ }^{2 *}$, Myat Kyaw-Tanner ${ }^{1}$, David L Duffy ${ }^{3}$, Puya Gharahkhani ${ }^{1}$, \\ Linda Vogelnest ${ }^{4}$, Kenneth Mason ${ }^{5}$ and Michael Shipstone ${ }^{6}$
}

\begin{abstract}
Background: Canine atopic dermatitis is an allergic inflammatory skin disease common in West Highland white terriers. A genome-wide association study for atopic dermatitis in a population of West Highland white terriers identified a $1.3 \mathrm{Mb}$ area of association on CFA17 containing canine protein tyrosine phosphatase non-receptor type 22 (lymphoid) PTPN22. This gene is a potential candidate gene for canine atopic dermatitis as it encodes a lymphoid-specific signalling mediator that regulates T-cell and possibly B-cell activity.

Findings: Sequencing of PTPN22 in three atopic and three non-atopic West Highland white terriers identified 18 polymorphisms, including five genetic variants with a bioinformatically predicted functional effect. An intronic polymorphic repeat sequence variant was excluded as the cause of the genome-wide association study peak signal, by large-scale genotyping in 72 West Highland white terriers (gene-dropping simulation method, $P=0.01$ ).

Conclusions: This study identified 18 genetic variants in PTPN22 that might be associated with atopic dermatitis in West Highland white terriers. This preliminary data may direct further study on the role of PTPN22 in this disease. Large scale genotyping and complementary genomic and proteomic assays would be required to assess this possibility.
\end{abstract}

\section{Findings}

Canine atopic dermatitis (AD) is an allergic inflammatory skin disease that is common in West Highland white terriers (WHWTs) [1]. Following a genome-wide association (GWAS) in a group of related WHWTs, we found a $1.3 \mathrm{Mb}$ area on CFA 17 which was significantly associated with the disease [2]. Based on its biological functions, expression patterns and proximity to this area of association, PTPN22 was selected as a candidate gene for $\mathrm{AD}$ in this population. This gene encodes a lymphoid tyrosine phosphatase (PTPN22), a signalling mediator that regulates generic and specialised immune functions in mammals [3]. Activation of $\mathrm{T}$ and $\mathrm{B}$ lymphocytes is a key event in the pathogenesis of atopic disease [4], and the disruption of these pathways could cause hyper-reactive pathogenic T-cell responses, as well as affect B-cell

\footnotetext{
* Correspondence: c.oleary@uq.edu.au

${ }^{2}$ Centre for Companion Animal Health, School of Veterinary Science, The

University of Queensland, St Lucia, Queensland, 4069, Australia

Full list of author information is available at the end of the article
}

selection, maturation and function [5,6]. In humans and dogs, genetic variants in the gene PTPN22 have been associated with auto-immune diseases [7-9]. In humans, these include psoriasis, a chronic immune-mediated inflammatory skin disease that shares susceptibility loci with human $\mathrm{AD}[10,11]$. To date, no association has been found between PTPN22 variants and atopic disease in humans [12].

The University of Queensland Animal and Human Ethics Committees, and the University of Sydney Animal Ethics Committee approved this study. Written consent was obtained from all participating dog owners.

Criteria used to classify dogs in the present study are described elsewhere [1]. Fourteen set of primers were designed with primer3 [13], to sequence a total of 12.6 $\mathrm{Kb}$ of PTPN22 in 14 PCR products (Table 1). Amplification reactions used the HotStar HiFidelity PCR Kit (QIAGEN Pty Ltd, Doncaster, Vic, Australia) and 0.5 $\mu \mathrm{M}$ (PCR products 5 and 12), $1.5 \mu \mathrm{M}$ (6 and 14) or 1 $\mu \mathrm{M}$ (remaining PCR products) of primers; at $55^{\circ} \mathrm{C}$ (PCR
C Biomed Central

(c) 2011 Roque et al; licensee BioMed Central Ltd. This is an Open Access article distributed under the terms of the Creative Commons Attribution License (http://creativecommons.org/licenses/by/2.0), which permits unrestricted use, distribution, and reproduction in any medium, provided the original work is properly cited. 
Table 1 Primer sequences used to amplify and sequence $12.6 \mathrm{~Kb}$ of canine PTPN22 in three atopic and three non-atopic WHWTs

\begin{tabular}{|c|c|c|c|c|c|c|}
\hline $\begin{array}{l}\text { PCR } \\
\text { product }\end{array}$ & $\begin{array}{l}\text { Forward amplification } \\
\text { primer }\end{array}$ & Reverse amplification primer & $\begin{array}{l}\text { Internal forward sequencing } \\
\text { primer }\end{array}$ & $\begin{array}{l}\text { Internal reverse sequencing } \\
\text { primer }\end{array}$ & $\begin{array}{l}\text { Predicted gene } \\
\text { region }\end{array}$ & $\begin{array}{l}\text { Product } \\
\text { size }\end{array}$ \\
\hline 1 & CCTCATCAGGTGCTCTTCGT & GGTTTTGCCTCTCTCCCTTC & TGAAGTGGAAGAGTCTCAGAGC & AGAAAAGGCAGAAGGCCAGT & 5'UTR, exon 1 & 1041 \\
\hline 2 & GGCTCTGTCCTGAATTGGAG & TCTGCCCTTACCAGGACACT & - & - & Exons 2,3 & 858 \\
\hline 3 & CCAAATAAGAGGTCGGGGTA & CTACTGGGAAAATGGGCAAA & AGAAAAGGGAAGGAAGGACA & TCTGTCCTTCCTTCCCTTITC & Exons 4,5 & 863 \\
\hline 4 & ACCACAGTTGACCTTGGATAA & AGATGAAGGCACATCATGGTC & - & ACATCAAAGGTCCCCTACTCC & Exons 6,7 & 1182 \\
\hline 5 & CCACTTGAACTGGTGAAGCA & ACCAGTCCTTCCACAACCAG & - & GGATGGAACCCCATATTGAA & Exons 8 & 1172 \\
\hline 6 & TGCTCTGGGAAGTAGGGATG & CAAGGCAAGGGACATAGGAA & AATCCACCACAACCAAACCT & AGCCCGTATTTCCAACTTCC & Exons 9,10 & 1267 \\
\hline 7 & CCGAAATGAGGTAGGCAAAC & GCCCTGTCACTCACCCTTAT & - & - & Exons 11 & 483 \\
\hline 8 & TGGAAACTCACCTCTITTGTGA & TाCTाTGAGAAGGAAAAGGAAGAA & CAGAGTGGGAGACAAAAGCA & CCAGCTCCTTGGTGTCTCTC & Exons 12,13 & 1296 \\
\hline 9 & GAAGCAGCAGAAAACCTCCTA & ACCCCACATCCTCTAGCACA & GATCCCCATTTGCATTGTTC & TGGCCCAATTCTTAGGAGTGT & Exons 14,15 & 889 \\
\hline 10 & GGGTAAAGGATGCGTTTTCA & TGGGAGCTATTATGGGAACC & - & - & Exons 16 & 332 \\
\hline 11 & TGAGGCTCCAGTTATGGTTCA & CAGTCTTGTTCTCAATCTGCTTC & AAGTGGGACCTAAATGGAAAAG & CCTITTCCATTTAGGTCCCACT & Exons 17,18 & 747 \\
\hline 12 & GGATGGGAAAAAGTAGCAAGG & TTCTGATACAAAGAGCCATAGCA & - & - & Exon 19 & 410 \\
\hline 13 & TTCCCTTAAGTGTTGGGCTTT & TTGGCTTTGGCTAGTCACATT & - & - & Exon 20 & 92 \\
\hline 14 & GGCTGAATTACCAAAGGTTGT & TTCACAAATCCATCGTCAGG & TCGCAAAATCTGACTTGTGG & GGGAGATGTGCAAGGAATTT & Exon 21, 3'UTR & 550 \\
\hline
\end{tabular}


Table 2 PTPN22 sequence variants identified by sequencing genomic DNA from three atopic and three non-atopic WHWTs.

\begin{tabular}{|c|c|c|c|c|c|c|c|c|c|c|c|c|c|c|}
\hline \multirow{2}{*}{$\begin{array}{l}\text { Sequence } \\
\text { variant } \\
\text { identity }\end{array}$} & \multirow{2}{*}{$\begin{array}{l}\text { Position } \\
\text { on CFA17 } \\
\text { (bp) })^{a, b}\end{array}$} & \multirow{2}{*}{$\begin{array}{l}\text { Predicted } \\
\text { location in } \\
\text { gene }\end{array}$} & \multirow{2}{*}{$\begin{array}{l}\text { Nucleotide in } \\
\text { reference } \\
\text { database }^{\text {b }}\end{array}$} & \multirow{2}{*}{$\begin{array}{l}\text { Sequence } \\
\text { of variant }\end{array}$} & \multirow{2}{*}{$\begin{array}{l}\text { Reference } \\
\text { SNP identity }\end{array}$} & \multirow{2}{*}{$\begin{array}{l}\text { Predicted } \\
\text { functional effect }\end{array}$} & \multirow{2}{*}{$\begin{array}{l}\text { Variant } \\
\text { risk } \\
\text { score }^{c}\end{array}$} & \multicolumn{3}{|c|}{ Atopic dogs } & \multicolumn{3}{|c|}{ Non-atopic dogs } & \multirow{2}{*}{$\begin{array}{l}\text { Cross-species } \\
\text { conservation of variant } \\
\text { nucleotide sequence }{ }^{b, d}\end{array}$} \\
\hline & & & & & & & & Dog 1 & $\operatorname{Dog} 2$ & $\operatorname{Dog} 3$ & $\begin{array}{l}\text { Dog } \\
4\end{array}$ & $\operatorname{Dog} 5$ & $\begin{array}{l}\text { Dog } \\
6\end{array}$ & \\
\hline 1 & 54759173 & UTR & C & $\mathrm{T}$ & rs22597162 & $\begin{array}{l}\text { Transcription } \\
\text { regulatory (score } \\
86.5 \text { ) }\end{array}$ & $1-3$ & $\mathrm{C} / \mathrm{C}$ & $\mathrm{C} / \mathrm{T}$ & $C / T$ & $C / C$ & $\mathrm{C} / \mathrm{C}$ & $\mathrm{C} / \mathrm{C}$ & Conserved in $10 / 10$ \\
\hline$\underline{2}$ & 54759006 & UTR & A & del & $\begin{array}{l}\text { New variant } \\
\text { (dbSNP ss } \\
315790492)\end{array}$ & $\begin{array}{l}\text { Transcription } \\
\text { regulatory (score } \\
87.7 \text { ) }\end{array}$ & $1-3$ & del/del & $\mathrm{del} / \mathrm{A}$ & $\mathrm{del} / \mathrm{A}$ & T/A & $\mathrm{del} / \mathrm{A}$ & $\mathrm{A} / \mathrm{A}$ & Conserved in $9 / 10$ \\
\hline 3 & 54742593 & Intronic & A & G & rs22597162 & NA & $0-2$ & $\mathrm{G} / \mathrm{G}$ & $\mathrm{G} / \mathrm{A}$ & $\mathrm{G} / \mathrm{A}$ & $\mathrm{G} / \mathrm{G}$ & $\mathrm{G} / \mathrm{G}$ & $\mathrm{G} / \mathrm{G}$ & Not conserved \\
\hline 4 & 54742027 & Intronic & A & $T$ & rs22559551 & NA & $0-2$ & $\mathrm{~T} / \mathrm{T}$ & $\mathrm{T} / \mathrm{A}$ & T/A & $\mathrm{A} / \mathrm{A}$ & T/A & A/A & Conserved in $6 / 10$ \\
\hline 5 & 54739568 & Intronic & $T$ & C & rs22559538 & NA & No risk & $\mathrm{T} / \mathrm{T}$ & $\mathrm{C} / \mathrm{T}$ & $C / T$ & $\mathrm{C} / \mathrm{C}$ & $\mathrm{C} / \mathrm{T}$ & $\mathrm{C} / \mathrm{C}$ & Not conserved \\
\hline 6 & 54739315 & Intronic & A & G & $\begin{array}{l}\text { New variant } \\
\text { (dbSNP ss } \\
315790493)\end{array}$ & NA & $0-2$ & $\mathrm{G} / \mathrm{G}$ & $\mathrm{G} / \mathrm{G}$ & $\mathrm{G} / \mathrm{G}$ & $\mathrm{A} / \mathrm{A}$ & $A / G$ & A/A & Not conserved \\
\hline 7 & 54738923 & Intronic & G & del & $\begin{array}{l}\text { New variant } \\
\text { (dbSNP ss } \\
15790494) \\
\end{array}$ & NA & No risk & del/del & del/del & del/del & $\begin{array}{l}\text { del/ } \\
\text { del }\end{array}$ & del/del & $\begin{array}{l}\text { del/ } \\
\text { del }\end{array}$ & NA \\
\hline 8 & 54738927 & Intronic & - & A & $\begin{array}{l}\text { New variant } \\
\text { (dbSNP ss } \\
315790495) \\
\end{array}$ & NA & No risk & $\mathrm{A} / \mathrm{A}$ & $\mathrm{A} / \mathrm{A}$ & $\mathrm{A} / \mathrm{A}$ & $\mathrm{A} / \mathrm{A}$ & $\mathrm{A} / \mathrm{A}$ & $\mathrm{A} / \mathrm{A}$ & NA \\
\hline 9 & 54734456 & Intronic & $\mathrm{T}$ & $C$ & rs22559532 & NA & $0-2$ & $\mathrm{C} / \mathrm{C}$ & $\mathrm{C} / \mathrm{T}$ & $\mathrm{C} / \mathrm{T}$ & $\mathrm{C} / \mathrm{C}$ & $\mathrm{C} / \mathrm{C}$ & $\mathrm{C} / \mathrm{C}$ & Not conserved \\
\hline 10 & 54734415 & Intronic & A & G & rs22559522 & NA & No risk & $\mathrm{A} / \mathrm{A}$ & $A / G$ & $A / G$ & $\mathrm{G} / \mathrm{G}$ & $\mathrm{A} / \mathrm{G}$ & $\mathrm{G} / \mathrm{G}$ & Conserved in $10 / 10$ \\
\hline 11 & 54717953 & Exonic & G & A & $\begin{array}{l}\text { New variant } \\
\text { (dbSNP ss } \\
315790496)\end{array}$ & $\begin{array}{l}\text { Synonymous } \\
\text { Splicing regulatory } \\
\text { (score 85.4) }\end{array}$ & $1-4$ & $\mathrm{G} / \mathrm{G}$ & $\mathrm{G} / \mathrm{G}$ & $\mathrm{G} / \mathrm{G}$ & $\mathrm{A} / \mathrm{A}$ & $\mathrm{A} / \mathrm{A}$ & A/A & Conserved in $7 / 10$ \\
\hline 12 & 54715779 & Intronic & $T$ & $C$ & rs22578128 & NA & $0-2$ & $\mathrm{C} / \mathrm{C}$ & $\mathrm{C} / \mathrm{T}$ & $C / T$ & $\mathrm{~T} / \mathrm{T}$ & $\mathrm{C} / \mathrm{T}$ & $\mathrm{T} / \mathrm{T}$ & Conserved in 2/10 \\
\hline$\underline{13}$ & 54709793 & $\begin{array}{l}\text { Intronic } \\
\text { (spice site) }\end{array}$ & $\begin{array}{l}\text { 17-T repeat } \\
\text { (wild) }\end{array}$ & $\begin{array}{l}22-T \\
\text { repeat } \\
\text { (variant) }\end{array}$ & $\begin{array}{l}\text { New variant } \\
\text { (dbSNP ss } \\
315790497)\end{array}$ & $\begin{array}{l}\text { Alternative } \\
\text { splicing regulatory } \\
\text { (score 3.39) }\end{array}$ & $3-4$ & $\begin{array}{l}\text { variant/ } \\
\text { variant }\end{array}$ & $\begin{array}{l}\text { variant/ } \\
\text { wild }\end{array}$ & $\begin{array}{l}\text { variant/ } \\
\text { wild }\end{array}$ & $\begin{array}{l}\text { wild/ } \\
\text { wild }\end{array}$ & $\begin{array}{l}\text { variant/ } \\
\text { wild }\end{array}$ & $\begin{array}{l}\text { wild/ } \\
\text { wild }\end{array}$ & Conserved in $10 / 10$ \\
\hline 14 & 54699432 & UTR & C & $\mathrm{T}$ & $\begin{array}{l}\text { New variant } \\
\text { (dbSNP ss } \\
315790498)\end{array}$ & NA & $0-2$ & $\mathrm{C} / \mathrm{C}$ & $C / C$ & $C / C$ & $T / T$ & $\mathrm{~T} / \mathrm{T}$ & $\mathrm{T} / \mathrm{T}$ & Not conserved \\
\hline 15 & 54698793 & UTR & G & $\mathrm{T}$ & $\begin{array}{l}\text { New variant } \\
\text { (dbSNP ss } \\
315790499) \\
\end{array}$ & NA & $1-3$ & $\mathrm{~T} / \mathrm{T}$ & $\mathrm{T} / \mathrm{T}$ & $\mathrm{T} / \mathrm{T}$ & $\mathrm{T} / \mathrm{T}$ & $\mathrm{T} / \mathrm{T}$ & $\mathrm{T} / \mathrm{T}$ & NA \\
\hline 16 & 54698788 & UTR & C & T & $\begin{array}{l}\text { New variant } \\
\text { (dbSNP ss } \\
315790500)\end{array}$ & $\begin{array}{l}\text { Transcription } \\
\text { regulatory (score } \\
85.4 \text { ) }\end{array}$ & $1-3$ & $\mathrm{~T} / \mathrm{T}$ & $\mathrm{T} / \mathrm{T}$ & $\mathrm{T} / \mathrm{T}$ & $\mathrm{C} / \mathrm{C}$ & $C / C$ & $\mathrm{C} / \mathrm{C}$ & Conserved in $7 / 10$ \\
\hline
\end{tabular}


Table 2 PTPN22 sequence variants identified by sequencing genomic DNA from three atopic and three non-atopic WHWTs. (Continued)

\begin{tabular}{|c|c|c|c|c|c|c|c|c|c|c|c|c|c|c|}
\hline 17 & 54698729 & UTR & $\mathrm{T}$ & $C$ & $\begin{array}{l}\text { New variant } \\
\text { (dbSNP ss } \\
315790501 \text { ) }\end{array}$ & NA & $1-3$ & $\mathrm{C} / \mathrm{C}$ & $\mathrm{C} / \mathrm{C}$ & $C / C$ & $\mathrm{C} / \mathrm{C}$ & $C / C$ & $\mathrm{C} / \mathrm{C}$ & NA \\
\hline 18 & 54698473 & UTR & $G$ & $T$ & $\begin{array}{l}\text { New variant } \\
\text { (dbSNP ss } \\
315790502 \text { ) }\end{array}$ & NA & 0 & $T / T$ & $\mathrm{~T} / \mathrm{T}$ & $\mathrm{T} / \mathrm{T}$ & $\mathrm{G} / \mathrm{G}$ & $\mathrm{G} / \mathrm{T}$ & $\mathrm{G} / \mathrm{G}$ & Conserved in $9 / 10$ \\
\hline
\end{tabular}

Sequence variants with a predicted medium to high disease-associated functional effect, with strongly conserved sequence across 10 mammals (dog, human, pig, horse, mouse, rat, cattle, chimpanzee, gorilla and orangutan) and differential distribution between atopic and non-atopic dogs are underlined (Sequence variant identities 1, 2, 11, 13 and 16)

${ }^{a}$ reverse strand; ${ }^{b}$ based on the $1.5 \times$ poodle genome (version 1) and the boxer 7.6x whole-genome sequences (CanFam2.0), accessed in March 2010 from http://www.ncbi.nlm.nih.gov and http://genome.ucsc.edu; ${ }^{c}$ as predicted by FASTSNP [5]; disease risk possibilities are 0 (no potential functional risk), 1 (very low risk), 2 (low risk) 3 (medium), 4 (high risk) and 5 (very high risk). FASTSNP provides a "risk score" for each SNP based predic by and orangutan); UTR: untranslated region (DNA); NA: not accessed; del: nucleotide deletion 
Table 3 Haplotypes constructed using 18 genetic variants of PTPN22

\begin{tabular}{|c|c|c|c|}
\hline \multicolumn{2}{|c|}{ Haplotype $^{a}$} & \multicolumn{2}{|c|}{ Number of chromosomes } \\
\hline & & \multirow{2}{*}{$\begin{array}{l}\text { Atopic dogs } \\
4 / 6\end{array}$} & \multirow{2}{*}{$\begin{array}{l}\text { Non-atopic dogs } \\
0 / 6\end{array}$} \\
\hline $\bar{A}$ & C-del-G-T-T-T-del-A-C-A-C-C-variant ${ }^{\mathrm{b}}$-C-T-T-C-T & & \\
\hline $\bar{B}$ & T-A-A-C-C-G-del-A-T-G-C-T-wild'-C-T-T-C-T & $2 / 6$ & $0 / 6$ \\
\hline$C$ & C-A-G-C-C-A-del-A-C-G-T-T-wildC-T-T-C-C-T & $0 / 6$ & $4 / 6$ \\
\hline $\mathrm{D}$ & C-A-G-C-C-A-del-A-C-G-T-C-wildC-T-T-C-C-G & $0 / 6$ & $1 / 6$ \\
\hline $\bar{E}$ & C-del-G-T-T-G-del-A-C-A-C-T-variant ${ }^{\mathrm{C}}$-T-T-C-C-T & $0 / 6$ & $1 / 6$ \\
\hline
\end{tabular}

${ }^{a}$ maximum-likelihood (Log likelihood $=-108.87$ ) haplotype assignment for the dogs as predicted by Superlink [7]; ${ }^{\mathrm{b}} 22-\mathrm{T}$ repeat allele; ${ }^{\mathrm{c}} 17-\mathrm{T}$ repeat allele; del: nucleotide deletion

product 8$), 57^{\circ} \mathrm{C}(3$ and 14$), 58^{\circ} \mathrm{C}(7,10$ and 13$), 64^{\circ} \mathrm{C}$ (5) or $60^{\circ} \mathrm{C}$ (remaining products) annealing temperatures. PCR products were purified with MinElute PCR Purification Kit (QIAGEN Pty Ltd, Doncaster, Vic, Australia), and bi-directionally sequenced at the Australian Equine Genetics Research Centre using $0.5 \mu \mathrm{M}$ (PCR product $3,4,5,12,14$ ) or $1 \mu \mathrm{M}$ (remaining PCR products) of forward and reverse amplification primers and $0.5 \mu \mathrm{M}$ of internal sequencing primers (Table 1 ), and BigDye Terminator v3.1 Cycle Sequencing Kit (Applied Biosystems, Foster City, CA, USA). Primers were supplied by GeneWorks (Hindmarsh, SA, Australia). Sequencing protocol was as recommended by the manufacturer, except annealing temperatures for PCR products 3,9 and 11 were $50^{\circ} \mathrm{C}$ and $60^{\circ} \mathrm{C}$ for PCR products 4 and 5.

Sequence data were analyzed with ChromasPro v1.5 (Technylisium, Tewantin, Qld, Australia) and compared with the $1.5 \times$ poodle (version 1 ) and the boxer $7.6 \times$ whole-genome sequences (CanFam2.0). Among 18 variants identified [14], five variants showed a medium to high disease-associated risk as predicted by FASTSNP [15] and Mutation Taster [16]; three single-nucleotide polymorphisms (SNPs) in a predicted regulatory region of the gene, one synonymous SNP, and a variable sequence repeat in a predicted splice site (Table 2). These variants formed five different haplotypes (Table 3). There were no recombinant events within this $12.6 \mathrm{~Kb}$ interval.
Variant sequence repeat c.2137-20 T(17_22) (Figure 1) has not been previously reported in dogs or other species and was bioinformatically predicted to have indirect structural effects on PTPN22. Comparable intronic repeat variations might interfere with normal gene expression [17-19] and have been associated with alternative splicing and disease in humans [20-23]. Thus, fluorescently labelled, amplified-fragment length genotyping of this variant was performed in 72 WHWTs, including 54 dogs from the GWAS. Primers and PCR conditions for amplification of PCR product 11 were used. Genotyping was performed on a 3130xl Genetic Analyzer (Applied Biosystems, Foster City, CA, USA) and analyzed using Genemapper (Applied Biosystems, Foster City, CA, USA). SIB-PAIR [24] showed no significant evidence for allelic association between this variant and the trait (gene-dropping simulation method, $P=$ 0.01). Large scale genotyping and complementary genomic and proteomic assays would be required to assess any potential effect of the remaining genetic variants in PTPN22.

\section{Availability of supporting data}

The data set supporting the results of this article is available in the National Center for Biotechnology Information Reference Assembly dbSNP repository, http:// www.ncbi.nlm.nih.gov/SNP/snp_viewTable.cgi? handle=O_LEARY_ATOPY.

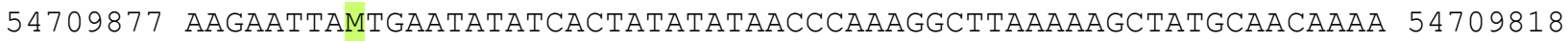 54709817 стGTтTтTтTтTтTтTтTTAAGGTATGCAGGCTCAGTCTATAGAGACTTCTTCTACTAG 54709758 54709757 CTGTCCTAGTACCATGGAAAATTCAACATCTTCAAAGCAGACATTAAAGACTCCTGGAAA 54709698 54709697 AAGTTTCACAAGGACTAAGGTAAAGAAGATGGGAGTTTTAAGAAATATGCCAGAGTCTTT 54709638

Figure 1 Relative location of the variant sequence repeat c.2137-20 T(17_22) in canine PTPN22. Exons in the gene are marked in yellow, variants annotated in web-based databases are in green and the new intronic variant identified by sequencing in three atopic and three nonatopic WHWTs is highlighted in pink. Line numbering is relative to coordinate system. 


\section{Acknowledgements}

This study was supported by the Centre for Companion Animal Health, the Australian Companion Animal Health Foundation, and the John \& Mary Kibble Trust to CAO. The authors also thank the owners of WHWTs, especially Lyndell Sequil Bristow.

\section{Author details}

${ }^{1}$ School of Veterinary Science, The University of Queensland, Gatton, Queensland, 4343, Australia. ${ }^{2}$ Centre for Companion Animal Health, School of Veterinary Science, The University of Queensland, St Lucia, Queensland, 4069, Australia. ${ }^{3}$ Genetic Epidemiology Laboratory, Queensland Institute of Medical Research, Herston, Queensland, 4029, Australia. ${ }^{4}$ The University of Sydney, University Veterinary Teaching Hospital, Camden, New South Wales, 2570, Australia. ${ }^{5}$ Dermcare, Springwood, Queensland, 4127, Australia. ${ }^{6}$ Dermatology for Animals, Stafford Heights, Queensland, 4053, Australia.

\section{Authors' contributions}

JBR was responsible for all experimental procedures, analysis and interpretation of data, manuscript writing and editing; CAO conceived and coordinated the study, contributed to the experimental design and to manuscript drafting and editing; MKT contributed to manuscript editing; DLD contributed to the experimental design, statistical analyses and manuscript editing; PG contributed to experimental procedures and analysis of data; LV, KM and MS were responsible for the diagnosis and recruitment of dogs. All authors contributed to the critical revision and approved the final manuscript.

\section{Competing interests}

The authors declare that they have no competing interests.

Received: 14 October 2011 Accepted: 30 December 2011 Published: 30 December 2011

\section{References}

1. Jaeger K, Linek M, Power HT, Bettenay SV, Zabel S, Rosychuk RAW, Mueller RS: Breed and site predispositions of dogs with atopic dermatitis: a comparison of five locations in three continents. Vet Dermatol 2010 21:118-122.

2. Roque JB, O'Leary CA, Kyaw-Tanner M, Gharahkhani P, Latter M, Mason K, Shipstone M, Vogelnest L, Duffy DL: Atopic dermatitis in West Highland white terriers is associated with $1.3 \mathrm{Mb}$ region on CFA 17 . Immunogenetics

3. Vang T, Miletic AV, Arimura Y, Tautz L, Rickert RC, Mustelin T: Protein tyrosine phosphatases in autoimmunity. Ann Rev Immunol 2008, 26:29-55.

4. Hill PB, Olivry T, (2001) The ACVD task force on canine atopic dermatitis (V): Biology and role of inflammatory cells in cutaneous allergic reactions. Vet Immunol Immunopathol 2001, 81:187-198.

5. Rieck M, Arechiga AF, Onengut-Gumuscu S: Genetic variation in PTPN22 corresponds to altered function of T and B lymphocytes. I Immunol 2007, 179:4704-4710.

6. Arechiga AF, Habib T, He Y, Zhang X, Zhang Z-Y, Funk A, Buckner JH: Cutting Edge: The PTPN22 Allelic Variant Associated with Autoimmunity Impairs B Cell Signalling. J Immunol 2009, 182:3343-3347.

7. Chung SA, Criswell LA: PTPN22: Its role in SLE and autoimmunity. Autoimmunity 2007, 40:582-590.

8. Short AD, Catchpole B, Kennedy L, Barnes A, Fretwell N, Jones C, Thomson W, Ollier WER: Analysis of candidate susceptibility genes in canine diabetes. J Hered 2007, 98:518-525

9. Roycroft M, Fichna M, McDonald D, Owen K, Zurawek M, Gryczyńska M, Januszkiewicz-Lewandowska D, Fichna P, Cordell H, Donaldson P, Nowak J, Pearce S: The tryptophan 620 allele of the lymphoid tyrosine phosphatase PTPN22 gene predisposes to autoimmune Addison's disease. Clin Endocrinol 2009, 70:358-362.

10. Giardina E, Sinibaldi C, Chini L, Moschese V, Marulli G, Provini A, Rossi P, Paradisi M, Chimenti S, Galli E, Brunetti E, Girolomoni G, Novelli G: Colocalization of susceptibility loci for psoriasis (PSORS4) and atopic dermatitis (ATOD2) on human chromosome 1q21. Hum Hered 2006, 61:229-236

11. Li Y, Liao W, Chang M, Schrodi SJ, Bui N, Catanese JJ, Poon A Matsunami N, Callis-Duffin KP, Leppert MF, Bowcock AM, Kwok PY, Krueger GG, Begovich AB: Further genetic evidence for three psoriasis- risk genes ADAM33, CDKAL1, and PTPN22. I Invest Dermatol 2009, 129:629-634.

12. Stene $L C$, Rønningen $K S$, Bjørnvold M, Undlien DE, Joner G: An inverse association between history of childhood eczema and subsequent risk of type 1 diabetes that is not likely to be explained by HLA-DQ, PTPN22, or CTLA4 polymorphisms. Pediatr Diabetes 2011, 11:386-393.

13. Rozen S, Skaletsky HJ: Primer3 on the WWW for general users and for biologist programmers. In Bioinformatics methods and protocols: Methods in molecular biology. Edited by: Krawetz S, Misener S. New Jersey: Humana Press; 2000:365-386.

14. The National Center for Biotechnology Information Reference Assembly dbSNP repository. [http://www.ncbi.nlm.nih.gov/SNP/snp_viewTable.cgi? handle=O_LEARY_ATOPY].

15. Yuan $\mathrm{H}-\mathrm{Y}$, Chiou J-J, Tseng W-H, Liu C-H, Liu C-K, Lin Y-J, Wang H-H, Yao A, Chen Y-T, Hsu C-N: FASTSNP: an always up-to-date and extendable service for SNP function analysis and prioritization. Nucleic Acids Res 2006, 34:635-644.

16. Schwarz J, Rodelsperger C, Schuelke M, Seelow D: MutationTaster evaluates disease-causing potential of sequence alterations. Nat Methods 2010, 7:575-576.

17. Fishelson M, Geiger D: Optimizing exact genetic linkage computations. J Comput Biol 2003, 11:263-275.

18. Hedjran F, Yeakley JM, Huh GS, Hynes RO, Rosenfeld MG: Control of alternative pre-mRNA splicing by distributed pentameric repeats. PNAS 1997, 94:12343-12347.

19. Meloni R, Albanèse $V$, Ravassard $P$, Treilhou F, Mallet J: A tetranucleotide polymorphic microsatellite, located in the first intron of the tyrosine hydroxylase gene, acts as a transcription regulatory element in vitro. Hum Mol Genet 1998, 7:423-428.

20. Roche R: Role of the intron 13 polypyrimidine tract in soluble Flt-1 expression. PhD thesis Virginia Polytechnic Institute and State University, Department of Biomedical Sciences and Pathobiology; 2002.

21. Viel M, Leroy C, Des Georges M, Claustres M, Bienvenu T: Novel length variant of the polypyrimidine tract within the splice acceptor site in intron 8 of the CFTR gene: consequences for genetic testing using standard assays. Eur J Hum Genet 2004, 13:136-138.

22. Meili D, Kralovicova J, Zagalak J, Bonafé L, Fiori L, Blau N, Thöny B, Vorechovsky: Disease-causing mutations improving the branch site and polypyrimidine tract: Pseudoexon activation of LINE-2 and antisense Alu lacking the poly(T)-tail. Hum Mutat 2009, 30:823-831.

23. David A, Miraki-Moud F, Shaw NJ, Savage MO, Clark AJL, Metherell LA: Identification and characterization of a novel GHR defect disrupting the polypyrimidine tract and resulting in GH insensitivity. Eur J Endocrinol 2010, 162:37-42.

24. Duffy D: SIB-PAIR.[http://www.qimr.edu.au/davidD].

doi:10.1186/1756-0500-4-571

Cite this article as: Roque et al: PTPN22 polymorphisms may indicate a role for this gene in atopic dermatitis in West Highland white terriers. BMC Research Notes 2011 4:571.

\section{Submit your next manuscript to BioMed Central and take full advantage of:}

- Convenient online submission

- Thorough peer review

- No space constraints or color figure charges

- Immediate publication on acceptance

- Inclusion in PubMed, CAS, Scopus and Google Scholar

- Research which is freely available for redistribution 